\title{
Interés general e interpretación contractual en Cuba*
}

\section{Arsul José Vázquez Pérez** \\ I Liuba Galbán Rodríguez ***}

RESUMEN. Este artículo aborda los problemas que afectan la definición de la noción de interés general y su interrelación con la libertad individual y otros valores. Los autores apuestan por el rescate de la noción de bien común para dotar de una fisonomía coherente la idea de interés general que más se aviene con el criterio de justicia equitativa. Finalmente, valora las implicaciones del reconocimiento en Cuba del interés general como criterio axiológico aplicable a la interpretación de los contratos y traza algunas pautas para su mejor aplicación al proceso de inteligencia contractual.

PALABRAS ClAVE: interés general, contrato, interpretación contractual.

* Fecha de recepción: 30 de octubre de 2019. Fecha de aceptación: 30 de marzo de 2020.

Para citar el artículo: VÁzQuez Pérez, A. J. y Galbán Rodríguez, L., "Interés general e interpretación contractual en Cuba", Revista de Derecho Privado, n. . 39, julio-diciembre 2020, 233-259, DoI: https://doi.org/10.18601/01234366.n39.10.

** Universidad de Oriente, Santiago de Cuba, Cuba; profesor de Derecho Civil y Derecho Mercantil. Doctor en Ciencias Jurídicas por la Universidad de Oriente, Santiago de Cuba, Cuba. Contacto: arsul@uo.edu.cu. Orcid: 0000-0002-3530-7366.

*** Universidad de Oriente, Santiago de Cuba, Cuba; profesora de Derecho Procesal. Doctora en Derecho por la Universidad de Antwerpen, Antwerpen, Bélgica y Doctora en Ciencias Jurídicas por la Universidad de Oriente, Santiago de Cuba, Cuba. Contacto: lgalban@uo.edu.cu. Orcid: 0000-00018576-5720. 


\section{General Interest and Contractual Interpretation in Cuba}

Aвstract. This paper addresses the problems that affect the definition of the notion of general interest and its interrelation with individual freedom and other values. The author is committed to the rescue of the notion of common good to provide a coherent face the idea of general interest that is more consistent with the criterion of fair justice. Finally, it assesses the implications of recognition in Cuban of general interest as an axiological criterion applicable to the interpretation of contracts and draws some guidelines for its better application to the contractual intelligence process.

KEYWORDS: general interest, contract, contract interpretation.

SUMARIO: Introducción. I. El interés general. Aproximación a su estatus. II. El contrato en la saeta del interés general. III. El interés general en la hermenéutica contractual cubana. Conclusiones. Referencias.

\section{Introducción}

En Cuba, la vigencia del Decreto-Ley n. ${ }^{\circ}$ 304, "De la contratación económica”, del 1. ${ }^{\circ}$ de noviembre de 2012, marcó la pauta en el reconocimiento formal de un grupo de principios generales que hasta la fecha carecían de expresión en el ordenamiento jurídico, o que eran cuestionados en su aplicabilidad por no estar definidos en el Código Civil de 1987. De este modo, autonomía de la voluntad, buena fe, igualdad entre partes, confidencialidad, relatividad del contrato, intangibilidad contractual e interés general fueron individualizados y filtrados al interior del derecho contractual mediante una controvertida disposición final cuarta ${ }^{1}$.

Lo relevante del acontecimiento no estuvo solo en reconocer de forma expresa parte del tejido axiológico que vigoriza el fenómeno contractual, sino en reseñalizar el puente entre la Constitución y la normativa aplicable al derecho de contratos en Cuba, pues el artículo 2. ${ }^{\circ}$ del Código Civil ${ }^{2}$ ya había fijado el patrón conectivo.

La idea dominante desde tiempos anteriores a la última codificación civil favoreció de manera muy intensa la "separación de cuerpos" entre derecho constitucional y derecho de contratos, y terminó de fraguarse con la omisión del sistema de fuentes

1 En la cuarta de sus disposiciones finales, el Decreto Ley n. ${ }^{\circ}$ 304/2012 establece: "Las normas de este Decreto-Ley, reguladoras de principios generales de la contratación, pueden ser de aplicación supletoria a otros contratos, cualquiera que sea su naturaleza, en lo no previsto para ellos por sus normas especiales y la legislación vigente".

2 Artículo 2. Las disposiciones del presente Código se interpretan y aplican de conformidad con los fundamentos políticos, sociales y económicos del estado cubano expresados en la constitución de la República. 
en el Código Civil, cuya expresión en el debate académico y práctico devino en una suerte de convicción en la que solo la ley era fuente del derecho ${ }^{3}$. Así, junto con la directa aplicabilidad de la Carta Magna, sucumbió el reconocimiento de los valores y principios jurídicos para su aplicación a la solución de conflictos contractuales, cualquiera que fuese su objeto.

Las consistentes críticas a la visión legal-formalista ${ }^{4}$, donde pueden incluirse algunos criterios del Tribunal Supremo Popular de la República de Cuba (TSP) ${ }^{5}$, y el expreso reconocimiento normativo del papel de los elementos axiológicos ${ }^{6}$, son ejemplos de un giro hacia la convergencia del derecho de contratos y el derecho constitucional, cuya genuina expresión es el artículo 8. ${ }^{\circ}$ del Decreto-Ley n. ${ }^{\circ}$ 304/2012.

La asimilación del interés general como principio de la contratación confirmó la posibilidad de invocar los fundamentos del sistema consagrado en la Constitución para la concertación, interpretación y ejecución contractual. Y fue confirmación, porque el interés general encontraba su plataforma de apoyo en el artículo 1. ${ }^{\circ}$ de la Ley de leyes desde la reforma de 1992, bajo las fórmulas gramaticales "con todos y para el bien de todos" y "bienestar individual y colectivo", que remiten al bien común como

3 Fue criterio de GriLlo Longoria que "Con respecto a los llamados 'principios generales del derecho', basta señalar que los propios autores burgueses no han podido ofrecer un sentido definido de estos elaborando formulaciones vagas, imprecisas, exigiéndose muchas veces para su validez jurídica su reconocimiento expreso por la jurisprudencia o por la ley". GrILlo LONGORIA, R., Derecho Procesal Civil, t. I. Teoría General del Proceso Civil, 3. ed., 1. reimp., La Habana, Félix Varela, 2006, 17.

4 Mendoza Díaz, J., "La fuentes formales del Derecho Procesal Civil”, en aA. vv., Lecciones de Derecho Procesal Civil, 1. a ed., 2. reimp., La Habana, Félix Varela, 2009, 9-18; Pérez Gallardo, L. B., "Breves notas sobre el Código Civil cubano a propósito de los veinte años de su promulgación. Especial referencia al Derecho de obligaciones y contratos", Revista Cubana de Derecho, n. ${ }^{\circ} 30$, juliodiciembre, 2007, 121; Arredondo SuÁrez, I. I., “¿Principios generales del Derecho en el sistema de fuentes?", "Justicia y Derecho”, Revista del Tribunal Supremo Popular de la República de Cuba, n. 14, año 8, junio de 2009, 47; Bruzón Viltres, C. J. y I. R. TAMAYo Blanco, "La jurisprudencia en Cuba: reconocimiento dentro del sistema de fuentes del Derecho y posibles consecuencias", Boletín Mexicano de Derecho Comparado, año XlVII, n. ${ }^{\circ}$ 139, enero-abril, 2014, 256; Bruzón Viltres, C. J., Condiciones para la validez formal de la jurisprudencia como fuente del Derecho en Cuba, tesis presentada en opción al grado científico de Doctor en Ciencias Jurídicas, Universidad de Oriente, Santiago de Cuba, 2016, 111.

5 “...] si bien normas de vital trascendencia como resultan la Constitución o la propia ley sustantiva se limitan a establecer los órganos con facultades normativas, no existiendo en nuestro ordenamiento precepto que enumere cuáles son sus fuentes y la relación de jerarquía entre éstas, es imposible desconocer como fuerza vinculante, sin atentar a su vez contra el principio de legalidad formal, el valor de fuente material e indirecta de los principios generales de Derecho que sirven de basamento natural de la legislación positiva al expresar valores, intereses e ideas rectoras que dominan la forma de interactuar la sociedad y que se materializan mediante la autointegración, cuando se da respuesta a un supuesto no reglado expresamente ya sea por analogía, aplicando una regulación existente para otro que tiene similitud con él [...]". Sentencia n. ${ }^{\circ} 219$, de 31 de marzo de 2006, Sala de lo Civil y de lo Administrativo del TSP, segundo considerando.

6 El Decreto-Ley n. ${ }^{\circ}$ 304/2012, en su quinto por cuanto expone: "Existen reglas y principios en materia de contratos, que deben ser expresamente reconocidos de manera que pueda ser exigida su observancia desde el proceso mismo de concertación, asegurando su mayor transparencia y contribuyendo a promover y asegurar las relaciones de cooperación entre las partes [...]". 
valor fundante del orden legal cubano, incluso con la reciente entrada en vigor de la nueva Constitución de la República, del 10 de abril de 2019[7].

Este hecho convierte al interés general en punto de encuentro de las piezas fundamentales del ordenamiento jurídico, al romper las pretendidas barreras entre lo privado y lo público, en tanto es un componente vital del valor constitucional que anuncia las metas inmediatas y esenciales de la convivencia humana. Además, su contenido transversal y contingente demuestra un vínculo con otros valores y principios jurídicos, constitucionales e infraconstitucionales, que garantizan su efectiva realización en la medida en que aquellos también son alcanzados. Mientras que su versatilidad deja ver una capacidad expansiva hacia las diferentes ramas y funciones del derecho, con especial mención para el derecho de contratos.

De este modo queda planteado el especial reto que para la interpretación contractual genera su confirmación como principio en el Decreto-Ley n. ${ }^{\circ}$ 304/2012, y las oportunidades que genera en el sentido de perfeccionar la actividad hermenéutica asumiendo una perspectiva integral y equitativa que ponga al cubierto los derechos de las partes involucradas.

Por tal motivo, resulta conveniente enfocar el problema de investigación en las siguientes interrogantes: ¿Qué alcance tiene para el ordenamiento jurídico cubano el reconocimiento del interés general como criterio axiológico aplicable a la interpretación de los contratos? ¿Cuáles pautas pueden contribuir en su adecuada aplicación del principio al proceso de inteligencia contractual?

Por su parte, el objetivo está orientado a analizar el alcance que tiene para el ordenamiento jurídico cubano el reconocimiento del interés general como criterio axiológico aplicable a la interpretación de los contratos, así como delimitar las principales pautas que permitan su aplicación de forma adecuada.

Para lograr este objetivo realizamos un acercamiento a los principales planteamientos que afectan la definición del principio, incluidos los aspectos que impiden o favorecen su adecuada individualización, sus confines o áreas de influencia y su interrelación con otros criterios axiológicos afines. Posteriormente se enfoca el estudio del principio en el fenómeno contractual y su comprensión como función social del negocio. Finalmente, se aborda el impacto del interés general en el proceso de la interpretación contractual, realizando el análisis de la normativa vigente en Cuba y el estudio de algunas sentencias puntuales de este ordenamiento jurídico, sin perder de vista algunos criterios que han tenido fuerte impacto en el derecho comparado.

7 El artículo 1. ${ }^{\circ}$ de la Constitución de la República de Cuba de 2019 mantiene una fórmula muy semejante a la de la derogada Constitución de 1976, reformada en 1978, 1992 y 2002. Vid. Constitución de la República de Cuba del 10 de abril de 2019, en Gaceta Oficial de la República de Cuba, Edición Extraordinaria, n. ${ }^{\circ}$, del 10 de abril de 2019. 


\section{El interés general. Aproximación a su estatus}

El interés general es un término recurrido, aunque no es frecuente encontrar una expresión legal que intente definirlo. Los sinónimos atribuidos a este concepto son variados, así: interés público, interés del Estado, bienestar colectivo y bien común. En lo relativo a la noción del bien común, en la actualidad se advierte la progresiva sustitución por la idea del interés general ${ }^{8}$. La razón de este reemplazo, en apariencia semántico, tiene importantes motivaciones ideológicas que no pueden perderse de vista y están en la sustancia del actual ciclo neoliberal.

La génesis del proceso de intercambio terminológico se debe a los planteamientos del liberalismo postrevolucionario de inicios del siglo XIX que contraponían la noción del bien común, de origen republicano, a la realización de la libertad individual. Por tanto, la existencia del gobierno y del Estado mismo no era más que un gravamen a la libertad personal para asegurar la protección del colectivo y, en esa misma medida, el ente político público devenía en representante y titular del interés común y límite a la libertad. Así, el enfoque individualista del bien común concibe esta "cesión" como un mal necesario para evitar la anarquía y asegurar, por encima de todo, la libertad del hombre?.

La arremetida contra el bien común, reducido y tergiversado a la fracción en que solo se privilegian los altos intereses de la comunidad frente a la libertad y la felicidad individuales, socavó también la noción ética y contrapuesta a la visión individualista del ejercicio de una libertad de signo positivo, y generó la evasión progresiva de su empleo. A ello contribuyeron las acciones de regímenes totalitarios en diferentes latitudes, las invasiones y conflagraciones bélicas, que siempre han encontrado justificación para la tiranía y el abuso en el falseamiento del bien común. De este modo, y por senderos más complejos y menos reducidos que esta síntesis extrema, la idea del bien común republicano cedió terreno a la visión liberal. En este orden de razonamientos, si se tiene en cuenta que el liberalismo es la ideología dominante de nuestros tiempos, resulta lógica la pérdida de estima de la idea del bien común y el surgimiento, en su lugar, de una noción más potable y técnica a la propuesta ideológica individualista ${ }^{10}$.

8 De Vega, P., "La democracia como proceso (consideraciones en torno al republicanismo de Maquiavelo)", Revista de Estudios Políticos (Nueva época), n. . 120, abril-junio, 2003, 29; Marco PerLes, G. S., "Bien común e interés general en la retórica de los poderes públicos: ¿conceptos intercambiables?, Anuario Filosófico, XLII, 3, 2009, 621-623.

9 Constant, B., Curso de política constitucional, t. 2, trad. Marcial Antonio López, Madrid, Imprenta de la Compañía, 1820, 90-100; Sobre la libertad de los antiguos y en los modernos, Madrid, Tecnos, 2002, 75; De Bustamante y Montoro, A. S., Introducción a la Ciencia del Derecho. Nociones liminares: El Derecho, vol. 1, 2. ${ }^{a}$ ed., La Habana, Jesús Montero, editor, 1942, 58-59; MARCo PerLes, "Bien común e interés general [...]", cit., 618-621.

10 Cruz Prados, A., Ethos y Polis. Bases para una reconstrucción de la Filosofía Política, Pamplona, eunsa, 1999, 348-350; De Bustamante y Montoro, Introducción a la Ciencia del Derecho..., cit., 58-59. 
El interés general es un concepto de índole instrumental que parte del enfoque de la libertad en una dimensión negativa y reivindica un espacio neutral para el individuo. Cuestión que prueba el influjo de la noción antitética entre bien común y libertad, con privilegio para la segunda, la apuesta por el divorcio entre derechos del sujeto y compromiso colectivo, y el intento velado de cercenar la interdependencia de los beneficios atribuibles a unos respecto de los otros.

Es de todo punto de vista contradictorio asumir al interés general como concepto sustituto del bien común y minimizar el argumento incontrovertible de que si se posee un derecho es porque otros están obligados a algo. Además, no es éticamente sustentable imponer una exigencia a otros fundados en necesidades estrictamente individuales. No es posible ligar a otros respecto de nosotros si ello no comporta el bien del otro, porque el bien común es el tejido conectivo que posibilita que los derechos del individuo sean auténticos derechos y no pretensiones arbitrarias. En consecuencia, no es viable la construcción coherente de una figura de interés general en el derecho moderno que no se someta a este punto esencial de la visión republicana de la libertad y el bienestar colectivo. Habrá que entender el término con un enfoque comprensivo de aquellas cuestiones que la colectividad estima muy importantes y que hacen referencia al conjunto de condiciones espirituales y materiales necesarias para que la sociedad pueda alcanzar sus metas, a la vez que permita proyectar una situación que facilite a los individuos conseguir sus propios fines, garantizando la intervención del Estado cuando el individuo o agrupaciones de este no sean capaces de alcanzar el objetivo por sí mismos ${ }^{11}$.

En un acercamiento apriorístico a la compleja existencia del interés general plantea la interrelación entre la colectividad y aquello que, circunstancial o permanentemente, ella valora como trascendente frente a cualquier postura o deseo individual. Por ello se refiere siempre a cuestiones inmediatas, directas y hasta materiales, de las que el sujeto colectivo hace depender su existencia, vitalidad o armonía. La idea del interés general es, en este orden, un esfuerzo conceptual que también intenta acercar el derecho a los fines más inmediatos y directos del colectivo ${ }^{12}$.

La marcada indeterminación del interés general radica, además, en un elemento contingente que solo puede ser corporificado mediante una decisión jurídica. No es

11 Pacheco G., M., Teoría del derecho, Santiago de Chile, Editorial Jurídica de Chile, 4. ${ }^{\text {a }}$ ed., 1990, 23-24; De la Torre Martínez, C., La recepción de la Filosofía de los Valores en la Filosofía del Derecho, 1. a ed., México, D. F., Editorial unAm, 2005, 256; GARZón VAllejo, I., "Bien común, pluralismo y derechos" en AA. vv., Ley, moral y razón. Estudios sobre el pensamiento de John M. Finnis a propósito de la edición de Ley natural y derechos naturales, 1. a ed., México, D. F., Juan B. Etcheverry (Editor), Instituto de Investigaciones Jurídicas unAM, 2013, 154-155; HuERTA OCHOA, C., "El concepto de interés público y su función en materia de seguridad nacional", en AA. vV., Seguridad pública. Segundo Congreso Iberoamericano de Derecho Administrativo, Cisneros Farías, G; J. Fernández Ruiz y M.A. López Olvera (coords.), 1. a ed., México, D. F., Instituto de Investigaciones Jurídicas unAm, 2007, 132-136; LóPEz CALERA, N., "El interés público: entre la ideología y el Derecho", Anales de la Cátedra Francisco Suárez, Universidad de Granada, n. 44, 2010, 124-129.

12 López CALera, "El interés público...", cit., 127. 
posible hablar de la existencia del interés general si no es en referencia a un caso concreto $^{13}$. Solo la ponderación le hace aflorar ${ }^{14}$, generalmente, con la formulación de interrogantes como estas: ¿Quién se afecta más si el tribunal accede o rechaza la pretensión X: la colectividad o el sujeto individual? ¿Qué consecuencias tendría para la colectividad si el tribunal accede o rechaza la pretensión X? ¿A cuántos sujetos, y en qué medida, les afectará negativamente la decisión? De este modo y por contradictorio que parezca, en la decisión justa y equilibrada de un caso atinente a intereses privados estará siempre en juego la protección del interés general ${ }^{15}$.

No hace falta mucha perspicacia para detectar la falacia de la contraposición liberal entre el bien común y la libertad, esta vez bajo el rótulo de "interés individual frente a interés general". El pleito filosófico, en los argumentos de los defensores del individualismo, enfoca el interés general como la suma de todos los intereses privados, exacerbando el contenido residual del bien común, ahora en otro cuerpo, y sustentado en la rotunda afirmación de que no hay voluntad general sino suma de voluntades. Este planteamiento embiste contra la existencia y autonomía de los intereses colectivos, proponiendo así una visión que no contribuye a la solución del problema.

La pugna entre interés general e interés individual ha generado diversas respuestas en el terreno jurídico. En especial cuando hay conflicto entre ambas dimensiones para el ejercicio de los derechos. La solución de mayor acogida es que al manifestarse la contraposición el asunto se resuelva privilegiando al interés general, porque en su égida gravitan los elementos de cohesión que garantizan la supervivencia del colectivo ${ }^{16}$. Sin embargo, si se es consecuente con el punto de vista del auténtico bien común que venimos defendiendo, no puede hablarse de una genuina contradicción entre intereses individuales y colectivos, sino que estos últimos, los generales, trascienden a los primeros. Si no, cómo explicar que en la defensa de ciertos intereses privados esté claramente involucrado el interés general. Tal es el caso sometido a la Corte Interamericana de Derechos Humanos (CIDH) con el número 12.054, donde una ciudadana ecuatoriana demandaba a la República del Ecuador, entre otros aspectos, por la falta de la justa indemnización que el Estado debía proporcionar a causa de la expropiación de un inmueble de su propiedad. En tal sentido, la CIDH acertadamente sostuvo $^{17}$ :

13 Huerta Ochoa, "El concepto de interés público...", cit., 134.

14 Este particular muestra una de las características esenciales de los principios, al adquirir mayor o menor fuerza (peso) según las circunstancias. En este sentido, cambia el modo de consideración

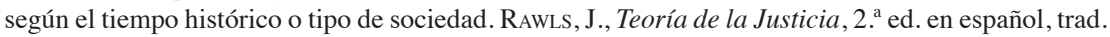
María Dolores González, 6. ${ }^{a}$ reimp., México, D. F., Fondo de Cultura Económica, 2006, 365.

15 LÓPEZ CALERA, "El interés público...", cit., 127-128.

16 Ibid., 147.

17 Sentencia Serie C n. ${ }^{\circ} 222$, del 3 de marzo de 2011, "Salvador Chiriboga vs. Ecuador", Corte Interamericana de Derechos Humanos, disponible en [www.corteidh.or.cr/CF/jurisprudencia2/ficha_tecnica.cfm?nId_Ficha=292], consultado: 13/09/2019. 
Este Tribunal estima que en el presente caso las razones de utilidad pública o interés social para la restricción del derecho de la propiedad privada de [la ciudadana] fueron legítimas y comprendieron la justificación necesaria para determinar dicha restricción. En consecuencia, las razones de utilidad pública o interés social son válidas [...]. Al respecto, el Tribunal estima que en casos de expropiación el pago de una indemnización constituye un principio general del derecho internacional, el cual deriva de la necesidad de buscar un equilibrio entre el interés general y el del propietario.

El ejercicio a ultranza del interés privado, su práctica egoísta o desmedida, es lo que colisiona con el interés general; lo mismo que si un órgano del Estado o los individuos ejercitan una determinada facultad de forma injusta, sin las garantías y el debido respeto a los derechos del afectado, habrá lugar a un atropello o despojo pero nunca se estará actuando en nombre del interés general. Las jurisprudencias salvadoreña y colombiana sostienen que en caso de presentarse un conflicto de esta índole el interés general en cuestión debe ser armonizado con el derecho o interés individual con el que choca, a fin de encontrar una solución que, a la luz de las particularidades del caso concreto, maximice ambos extremos de la tensión ${ }^{18}$.

En realidad, de lo que se trata cuando hay referencia al interés general no es de la manifestación per se de dos extremos en tensión, sino de una interrelación de facultades, derechos y obligaciones, donde las partes pretenden un fin legítimo, reconociéndose correlativamente en ese ejercicio interconectado y despojados de arbitrariedad o egoísmo. Así, en el caso de referencia, la expropiación por el Estado sin la adecuada indemnización es arbitraria, desapegada de la equidad, la justicia, desconocedora de las responsabilidades del poder público y distante del interés general. En igual sentido, negarse a la expropiación debidamente ejecutada y, consecuentemente, resistirse a recibir la apropiada indemnización no sería otra cosa que un desconocimiento de la autoridad legítimamente constituida y un ejercicio egoísta y antijurídico del interés individual.

Por otro lado, si el Estado ejercita sus facultades en un marco garantista, equitativo y justo que reconozca los derechos de la ciudadana y ella acata, reconociendo así el ejercicio de las potestades estatales, ambos estarán actuando en perfecta armonía con el bien común, o el interés general. Y en tal caso no hace falta armonización.

El interés general tuvo muy concretas expresiones en las codificaciones civiles y comerciales del siglo XIX, al invocarse fundamentalmente en supuestos limitantes del ejercicio del derecho de propiedad o de asociación económica, lo cual se mantiene como constante en los códigos aprobados durante el siglo xx y en los que han

18 Sentencia 19-VII-1996 de la Sala Constitucional de la Corte Suprema de Justicia de la República de El Salvador; sentencia C-539 de 1999, ratificada por la sentencia C-053, del 23 de enero de 2001, Corte Constitucional de la República de Colombia. 
entrado en vigor durante este siglo XXI ${ }^{19}$. El siglo Xx es también el período en el que la figura fue extendida al marco constitucional como una meta general de la sociedad y el Estado, adquiriendo un mayor relieve en su aplicación a las diferentes ramas del ordenamiento jurídico, aspecto que ha sido revitalizado por el constitucionalismo latinoamericano en tiempos más recientes ${ }^{20}$. La constitucionalización de esta figura le ha concedido, junto a otros elementos axiológicos, el rango de valor constitucional, meta fundamental de la sociedad y de los poderes públicos en su multiplicidad de formas y órdenes, para su efectiva realización y consolidación ${ }^{21}$.

19 Algunos ejemplos así lo ilustran: art. 545 del Código Civil francés de 1804; art. 559 y 1960 del Código Civil de la República de Chile de 1857; art. 554 y 1748 del Código Civil de la República de El Salvador de 1859; art. 349 del Código Civil del Reino de España 1888.

Esta tendencia se mantuvo hasta bien avanzado el siglo xx: arts. 828; 831; 844 y 933 del Código Civil Federal de los Estados Unidos Mexicanos de 1928; art. 56 del Código Civil de la República de Italia de 1942; arts. 5; 134.1; 172.1 y 216 c) del Código Civil de la República de Cuba de 1987; arts. 168; 1970 y 1973 del Código Civil y Comercial de la Nación Argentina de 2014.

20 Los Estados que han sufrido devastaciones a causa de la guerra o cruentas dictaduras suelen redactar textos donde explícitamente se acude al concepto del bien común: Preámbulo, art. 1 y 9. 2) Ley Fundamental de la República Federal Alemana de 1949; Preámbulo de la Constitución de la República Francesa de 1958; Preámbulo de la Constitución del Reino de España de 1978; art. 1 de la Constitución Política de Colombia de 1991.

El constitucionalismo latinoamericano ha relanzado el concepto del bien común, sentando las bases legales de la soberanía nacional, la superación de la pobreza, la desigualdad y la conflictividad social que dejaron las políticas neoliberales de la década de 1980. Véase Preámbulo de la Constitución de la República Bolivariana de Venezuela de 1999; Preámbulo y art. 3 de la Constitución de la República del Ecuador de 2008; Preámbulo y art. 8 de la Constitución Política del Estado Plurinacional de Bolivia de 2009.

21 Peces-Barba, G., Introducción a la Filosofía del Derecho, Madrid, Editorial Debate, 1990, 56; Los valores superiores, Colección Temas Claves de la Constitución Española, Madrid, Tecnos, 1984, 38; Del Rosario Rodríguez, M. F., "La supremacía constitucional: naturaleza y alcances", (en línea) Díkaion, año 25, vol. 20, n. ${ }^{\circ}$ 1, 2011, 100, en [https://dikaion.unisabana.edu.co/index.php/dikaion/ article/view/1950] [consultado el 12 de enero de 2018]; Ríos Álvarez, L., "Trascendencia de los Valores en las Constituciones Políticas de Chile y España”, Estudios Constitucionales, Revista del Centro de Estudios Constitucionales de Chile, año 1, n. ${ }^{\circ}$ 1, 2003, 761; Mariño, A., Castellanos, J.; Méndez López y D. Cutié Mustelier, "Los valores superiores del ordenamiento jurídico, pilar básico del texto constitucional", Barco de Papel, Memorias de la IV Conferencia Científica sobre Derecho, Facultad de Derecho de la Universidad de Oriente-Facultad de Derecho Eugenio María de Hostos, Mayagüez de Puerto Rico, 6-8 de octubre, 1997, 149-150.

En Cuba, el bien común como destino de la nación ha sido una idea fija en el pensamiento de los constituyentes y el liderazgo revolucionario, según el período histórico. En las constituciones mambisas, mediante las decididas alusiones a la conformación de un Estado-Nación con forma republicana, independiente de España, reconocedor de la libertad e igualdad de los ciudadanos. MARTí, J., "Discurso en el Liceo cubano, Tampa, 26 de noviembre de 1891", Obras Completas, vol. 4. Política y Revolución Iv, 1895. Discursos Revolucionarios, La Habana, Centro de Estudios Martianos y Karisma Digital, 2001, 267-279; Constitución de Guáimaro. Constitución política que regirá en Cuba mientras dure la guerra de independencia, del 10 de abril de 1869; Constitución de Jimaguayú, del 16 de septiembre de 1895; Constitución de la Yaya, del 30 de octubre de 1897.

En la República neocolonial, ya en el siglo xx, la idea del bien común se reitera a través del tiempo. Vid. Preámbulo Constitución de 1901; Preámbulo y artículo 1. e la Constitución de la República de Cuba del 10 de octubre de 1940.

Las constituciones cubanas de la etapa revolucionaria, específicamente la de 1976, reformada en el año 1992 y 2002 y la vigente, del 10 de abril de 2019, retoman el ideal político martiano de un Estado 
Adquirida esta cualidad, su influjo no se agota con el mero reconocimiento en la Carta Magna, pudiendo alcanzar realizaciones diversas en el ordenamiento jurídico. Entre ellas destaca su empleo como fuente de los diseños legislativos, el reconocimiento, desarrollo y las garantías de los derechos y servir como fundamento en la interpretación, aplicación, evolución e inclusión de otros inherentes al ser humano. En este sentido el interés general funge como baremo protector del modo en que se ejercitan, limitan o colisionan los derechos, funciones y facultades que ofrecen el engranaje constitucional y legal. Es preciso reconocer que la fórmula adoptada en el fuero normativo constitucional es muy cercana al bien común republicano o, directamente inspirado en este, sobre todo cuando se le nombra en los preámbulos o cuando se le asigna el pedigrí de fin del Estado y valor constitucional; mientras que al enfocarse en ramas específicas del ordenamiento jurídico o expresiones concretas del desarrollo del texto constitucional, se nos muestra con un matiz de principio instrumental, como una manifestación particularizada del valor.

El derecho administrativo ha sido el territorio de mayor fertilidad para el concepto en su expresión instrumental más acabada, y es allí donde adquiere ribetes de esencialidad, a partir de la idea de que todo el mecanismo estatal debe estar orientado a satisfacer el interés general. Así, fija su utilidad en el planteamiento ideológico de que las metas de la sociedad y el Estado son absolutamente coincidentes, asumiendo el ente político público el rol de "conciliador" de los intereses individuales, grupales y colectivos. Unido esto al anclaje del concepto en el bien común y la visión republicana de la voluntad general, se erige en el fundamento del modo de ser o estar de la Administración Pública que justifica su existencia. Razonamiento que, ajustado a los códigos de la función administrativa, señala al interés público como el interés general de la comunidad asumido por la Administración, configurando la dimensión subjetiva del concepto ${ }^{22}$.

A esta presunción, iuris tantum si se quiere, debe señalarse lo siguiente, en correspondencia con los planteamientos que se vienen fundamentando: No siempre que la administración pública actúa, lo hace representando el interés general. En principio, puede decirse que es la titular del interés público en el ámbito de su competencia y funciones, sin embargo, existe la posibilidad de destruir esta presunción en el terreno judicial. La sentencia del 29 de marzo de 2017 de la Sala de lo Contencioso del Tribunal Supremo español es una prueba evidente cuando expresa:

justo, equitativo y solidario, basado en la unidad de todos los elementos de la Nación, al adoptar en sus respectivos artículos primeros una fórmula que tiene su precedente jurídico más notable en la mentada Constitución de 1940. Este hecho es una muestra de la experiencia alcanzada en la evolución del pensamiento iusfilosófico cubano, y posibilita la continuidad a las ideas más positivas y progresistas gestadas durante la historia constitucional de Cuba en sus distintas etapas.

22 RodrígueZ-Arana, J., "El interés general en el derecho administrativo: notas introductorias", Revista Ópera Prima de Derecho Administrativo, Instituto de Investigaciones Jurídicas UNAM, $\mathrm{n} .^{\circ} 11$, enerojunio, 2012, 70; LóPez CALERA, "El interés público...", cit., 129-130; De Cores, C. A., y CAL, J. M., "El concepto de interés público y su incidencia en la contratación administrativa", Revista de Derecho de la Universidad de Montevideo, n. ${ }^{\circ}$ 11, año vi, 2007, 132. 
[...] la afirmación, sin más, de que una determinada doctrina provoca una reducción de los ingresos fiscales del Estado no lleva como consecuencia automática que sea gravemente dañosa para el interés general, pues, desde la perspectiva fiscal, este último no consiste en recaudar más [...], sino en obtener la recaudación que derive de la realización de un sistema tributario justo [...].

La creencia de que fallar contra la administración pública es una vulneración al interés general es falsa. No basta con ser titular de ciertas funciones estatales para actuar contra individuos aislados o una colectividad de ellos bajo el argumento del interés público. Es indispensable la identificación y fundamentación de aquello que se estima es el interés general y su ejercicio bajo criterios equilibrados y justos ${ }^{23}$.

El reconocimiento jurídico del interés general y su determinación conceptual han enfrentado, además, escollos asociados a su interdependencia y complementariedad con el sistema de valores constitucionales y a las dificultades que se derivan de la amplitud de su contenido y la concomitancia con otros elementos axiológicos, como la justicia, la equidad y la solidaridad ${ }^{24}$. Perfilar su área de influencia puede resultar una tarea de dimensiones incalculables, porque es el vaso comunicante de todas las dinámicas del orden político y jurídico ${ }^{25}$. Pero una cosa sí debe quedar

23 Así lo ha dicho la sentencia 19-VII-1996 de la Sala Constitucional de la Corte Suprema de Justicia de la República de El Salvador: “[...] sólo pueden tener como último objetivo la realización de los fines éticos de la persona humana; por tanto, los órganos estatales no deben perder de vista que su actividad siempre debe orientarse a la realización de la persona humana, tanto en su dimensión individual como social, sin anteponer a este objetivo supremo, supuestos 'fines' de la colectividad como conjunto orgánico, o del Estado como ente superior a aquélla, pues en este caso su actuación devendría en inconstitucional [...]".

La propia Sala Constitucional, en Sentencia 23-III-2001 ha expresado: “[...] la ordenación tendente al bien común se rige por la justicia general, y el mismo bien común se convierte en finalidad del orden social y en objeto de la justicia legal; por lo tanto, existe una conexión estrecha entre el bien común y la justicia".

24 Rouseau, J. J., El Contrato Social o Principios de Derecho Político, s/l, Ediciones elaleph.com, 1999, 164; Kelsen, H., Teoría Pura del Derecho, 1. a ed., 2. reimp., trad. 2. a ed. alemana Roberto J. Vernengo, México, D. F., Instituto de Investigaciones Jurídicas unAM, 1982, 354; HART, H. L. A., El concepto del Derecho, trad. Genaro R. Carrió, 1. a ed. inglesa, Buenos Aires, Abeledo-Perrot, 1998, 207; VoN IHERING, R., El fin en el Derecho, trad. Leonardo Rodríguez, Madrid, B. Rodríguez Serra Editor, s/f, 237; Rawls, Teoría de la Justicia, cit., 359-409; PAcheco G., Teoría del derecho, cit., 23; AleXY, R., Teoría de los derechos fundamentales, trad. español Ernesto Garzón Valdés, Madrid, Editorial Centro de Estudios Constitucionales, 1993, 479; Santiago Nino, C., "Justicia", Doxa, n. o 14, 1993, 67.

25 Importantes autores ubican en su territorio a los derechos humanos, con especial atención a los de tercera generación; el progreso económico que garantice bienes materiales bajo un orden justo de distribución de la riqueza; acceso amplio a bienes y medios del desarrollo y promoción de la cultura, la educación y formación intelectual; la justicia social, entendida como expresión de todas las formas de justicia; la seguridad jurídica. FABELo CoRzo, J. R., Los valores y sus desafíos actuales, 1. ' ed. (digital), s/1, Editorial Libros en Red, 2004, 64; ViLloro, L., El poder y el valor. Funda-

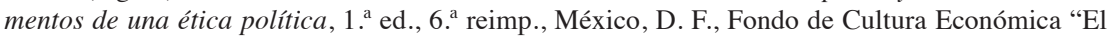
Colegio Nacional", 2012, 62; García Rosales, L. A., "La discriminación, el derecho de admisión y el derecho a la igualdad”, en AA. vv., Principios y valores constitucionales, Bogotá, Ediciones Civilizar, 2005, 227. 
clara a la hora de tomar la dimensión de la autonomía del interés general como concepto, y es el hecho de que comparta una extensa frontera con otros elementos axiológicos y de que la realización de aquellos implique, en mayor o menor medida, la realización de este no es un argumento definitivo para negarle autonomía. En todo caso, muestra elementos antes no revelados sobre el funcionamiento sistémico de las piezas del orden jurídico.

Como ya hemos referido, la identificación del interés general tiene un importante componente casuístico. Lo deja muy claro el fallo del Primer Tribunal Colegiado en materia administrativa del Primer Circuito de la Suprema Corte de Justicia de los Estados Unidos mexicanos:

No basta que el acto se funde formalmente en una ley de interés público, o que en forma expresa o implícita pretenda perseguir una finalidad de interés social [...] sino que es menester que las autoridades o los terceros perjudicados aporten al ánimo del juzgador elementos de convicción suficientes para que pueda razonablemente estimarse que, en el caso concreto que se plantee, la concesión de la suspensión causaría tales perjuicios al interés social, o que implicaría una contravención directa e ineludible, prima facie y para los efectos de la suspensión, a disposiciones de orden público, no sólo por el apoyo formalmente buscado en dichas disposiciones, sino por las características materiales del acto mismo ${ }^{26}$.

El hecho de que genere desconcierto obedece a estas características y también suele ser la causa de que en el intento de precisar su contenido se corra el riesgo de ensancharlo en un extremo tal que se le atribuya falta de autonomía. Por esto no puede confundirse la zona de influencia de la categoría objeto de estos comentarios con el contenido de los derechos humanos, por solo citar un ejemplo. Una asimilación en esa dirección sería un verdadero salto al vacío y no contribuye al esclarecimiento. ( $V . g r$., no es lo mismo el derecho humano a la vida en su estructura y contenido que promover, proteger y garantizar el derecho humano a la vida.) La definición del contenido del interés general por asimilación del cuerpo conceptual de otras instituciones es un error que puede llevar a entenderlo como una cápsula que engloba en su espectro todo aquello que hace bien al colectivo, algo que no amerita mucho esfuerzo teórico. Por tal razón, debe ser permanente, en aras de la precisión del contenido del interés general, el análisis equilibrado de los derechos individuales, grupales y colectivos en relación con los fines de la sociedad dada, su interdependencia o antagonismo en una situación concreta.

26 Tribunales Colegiados de Circuito. Séptima Época. Apéndice 1917-septiembre 2011, t. II. Procesal Constitucional 1. Común Segunda Parte-TCC Novena Sección. Suspensión del acto reclamado Subsección 1-Reglas generales, 2598. 


\section{El contrato en la saeta del interés general}

En el ámbito contractual, el interés general es un espacio donde se disuelven las fronteras entre el derecho público y el derecho privado, dotando al negocio jurídico de función social. Esta cual puede ser entendida como una institución fundada en el bien común, la solidaridad y la justicia social que contradice la lógica liberal del mercado autorregulado, donde el contrato no es mera transacción patrimonial para la maximización de beneficios y rentabilidad económica, sino que debe coadyuvar, además, el cumplimiento de ciertas metas sociales y de protección ambiental, así como evitar o modular los desequilibrios que se suscitan entre los actores preponderantes por su fuerza económica y aquellos con menor capacidad de negociación. De este modo, la función social del contrato es la expresión concentrada, en estos predios, del llamado interés general ${ }^{27}$.

El principio en cuestión se configura como un límite a la autonomía de la voluntad que privilegia las instituciones y formas de actividad económica que favorecen un desarrollo humano equitativo, justo y protector del ambiente, donde el proceso de creación y circulación de la riqueza no provoque desequilibrios desorbitantes, tendientes a la explotación desmedida de unos por otros. Al respecto, quienes con la debida autorización administren bienes o áreas del sector público pueden crear riqueza propia, pero nunca podrán hacerlo en desmedro de aquellos con quienes interactúan, ni de aquel que posee la titularidad del bien o área concedida. Deben incluirse en el supuesto los sujetos que entran en contacto con bienes o áreas del sector público en sus relaciones con empresas estatales, con el fin de beneficiarse leoninamente, sobre la base de la ineficiencia o el descontrol de los encargados de gestionar dichos activos. En esta órbita se encuentran las relaciones contractuales que involucran recursos de origen natural, creaciones humanas, símbolos de la cultura nacional o mundial, cuya transferencia, explotación o uso puede generar una lesión a la soberanía y estabilidad nacional, al patrimonio material o inmaterial, destrucción o menoscabo del ambiente y la salud humana ${ }^{28}$.

27 Bernal Fandiño, M., El deber de coherencia en el Derecho colombiano de los contratos, 1. a ed., Bogotá, Pontificia Universidad Javeriana, 2013, 23; ZenEdin GLITZ, F. E., La globalización del derecho contractual, trad. María Noel Antas, Sao Paulo, Editora Clásica, 2012, 330-331; Moráis Carvalho, J., "La protección de los consumidores en la Unión Europea. ¿Mito o realidad?”, Criterio Jurídico, Revista de la Pontificia Universidad Javeriana, vol. 6, 2006, 264; Benettr Timm, L., "La función social del Derecho contractual en el Código Civil brasileño: justicia distributiva vs. eficiencia económica", Revista de Instituciones, ideas y mercados, n. ${ }^{\circ}$ 52, mayo de 2010, 16.

El artículo 241 del Código Civil brasileño de 2002 reconocen la función social del contrato, mientras que el reciente Código Civil argentino de 2014 en su artículo 14 reprueba el ejercicio abusivo de los derechos individuales cuando estos afectan al medio ambiente o los derechos de incidencia colectiva general (difusos o de tercera generación).

28 De la Constitución de la República de Cuba de 2019, vigente desde el 10 de abril de 2019, pueden citarse entre otros los siguientes artículos: $11 ; 13 ; 23 ; 24 ; 71 ; 72 ; 75$ y 90. 
Las relaciones contractuales donde unos sujetos ofertan bienes o servicios esenciales o de amplia distribución, en condiciones de superioridad económica o de conocimiento, a un número elevado de ciudadanos que poseen el estatus de consumidores y usuarios, están vinculadas al interés general. La posibilidad de que consumidores y usuarios, eslabón débil del comercio, puedan ser sorprendidos colectivamente en su buena fe, no se les preste la información necesaria y comprensible, o se abuse de su ignorancia para obtener ventajas desproporcionadas, constituye razón suficiente para que las relaciones contractuales queden integradas a este argumento tuitivo ${ }^{29}$.

Siguiendo el hilo constitucional cubano, el Decreto Ley n. ${ }^{\circ}$ 304/2012 concretó de manera indubitada la presencia del interés general en el derecho contractual ${ }^{30}$. Este aspecto le confiere novedad en el concierto normativo, ya que la letra de su artículo 8..$^{\circ}$ es una contribución al intento de constitucionalizar la visión iusprivatista del negocio jurídico en Cuba, orientada a alcanzar las metas que encierra este principio, expresión de un valor fundamental.

Como texto, habilita el interesante debate acerca de la influencia de los factores ideológicos y políticos sobre el contrato, y reconoce el impacto del bien común, junto a los demás valores que fundan el ordenamiento jurídico, en el proceso de concertación, interpretación y ejecución del contrato. Así, el precepto de referencia dispone: "En la concertación, interpretación y ejecución de un contrato, las partes han de cumplir las regulaciones administrativas y no contravenir o dañar el interés público, la economía nacional, el medio ambiente y el orden social".

La interesante regulación, más allá de su acento grandilocuente, abre la oportunidad de aplicar con determinación y coherencia un concepto muy beneficioso para la práctica del derecho en Cuba, siempre que los tribunales de la República no lo asuman como un criterio que solo adquiere sentido cuando se protegen los intereses del Estado (administración pública) o sus empresas frente a los restantes actores, negando la posibilidad de armonía y compatibilización con los intereses de otros sujetos. Y es necesario abandonar un lastre tan pernicioso en estos tiempos, debido a sus negativos impactos en la justeza y equidad de las decisiones que alcanzan ciertos sujetos de la economía cubana, en particular, y a los actores sociales, en general.

En este sentido, las sentencias 35, 36 y 37, del 31 de marzo de 2014, dictadas por la Sala de lo Económico del Tribunal Supremo Popular de la República de Cuba sirven como muestra de estudio. De manera general las tres resoluciones fueron dictadas en el marco de contratos de prestación de servicios, para la reconstrucción de

29 El resultado de la aplicación del interés general incluye el auxilio del principio de la buena fe, toda vez que el bien común supone la colaboración de los sujetos para alcanzar el bienestar. ÁvILA SANTAMARÍA, R., "Ecuador, Estado constitucional de derecho y de justicia", en AA. vv., La Constitución del 2008 en el contexto andino. Análisis desde la doctrina y el derecho comparado, 1. a ed., Quito, Editorial del Ministerio de Justicia y Derechos Humanos, 2008, 27-28; Bernal FandiÑo, El deber de coherencia..., cit., 24.

30 Aplicable a la contratación civil en virtud de la mencionada Disposición Final Cuarta del propio Decreto Ley n. ${ }^{\circ}$ 304/2012. 
unos objetos de obra en cierto cementerio patrimonial. El reclamo de los recurrentes, todos trabajadores por cuenta propia, consistía en que determinada unidad presupuestada del Estado abonara el valor de las prestaciones realizadas con anterioridad a marzo de 2013, lo cual fue debidamente probado según las sentencias mentadas.

$\mathrm{El}$ argumento central defendido por el órgano jurisdiccional en cada una de las sentencias radicó en el hecho de que los recurrentes exigían un precio que no habían probado durante el proceso $\mathrm{y}$, consecuentemente, una indemnización por mora que no tenía modo de ser calculada por no existir base demostrada para ello, pues el contrato en el que amparaban su reclamación se había firmado con posterioridad a la ejecución de las prestaciones que motivaban el reclamo. De este modo, la inexistencia de "evidencia documental" en la que se individualizaran el precio y demás condiciones generaba la ineficacia de la relación contractual, anterior a marzo de 2013, en la que los trabajadores por cuenta propia fundaban su reclamo. Por último, la Sala incorporó a su discurso desestimatorio lo que denominó "exorbitante cantidad" de dinero que exigían los recurrentes en concepto de precio pactado por las prestaciones ya ejecutadas y probadas, al afirmar en el primero de sus considerando con respecto a la cláusula no escrita del precio que "[...] aún dispuesta y resultando de ella acuerdo contrario al orden público o al interés social, no puede ser sancionado judicialmente validándolo [...]”. De lo que puede colegirse que los recursos interpuestos contra las tres resoluciones no tuvieron éxito alguno.

La pregunta de rigor: ¿Aplicó la Sala de modo correcto el principio de interés general? La respuesta: no. Muchas razones pueden amparar este juicio, pero en este caso centraremos los argumentos en las respuestas a las siguientes interrogantes: (1) ¿Había una auténtica contradicción entre el interés general y el interés de los trabajadores por cuenta propia? (2) ¿La solución socialmente más valiosa era aquella que desconociera el valor de los trabajos realizados?

La primera interrogante habría tenido una respuesta muy simple si la solución hubiese identificado el norte de la contradicción, que no radicaba estrictamente en la cuantía, sino en la equidad. En consecuencia, si los trabajadores concertaron una relación jurídica con una entidad estatal en la que esta debía pagar los trabajos realizados por aquellos con un precio excesivo, lo justo habría sido, en virtud del interés general, impedir el despilfarro de los fondos públicos y el consiguiente daño económico al Estado, pero reconociendo que los trabajos efectivamente realizados tienen un valor en el mercado. El tribunal debió reconocer el derecho a cobrar la suma adecuada que permitiera recuperar el costo más la ganancia razonable, que a la postre permite a estos sujetos de la economía mantenerse en el desempeño de la actividad.

No obstante, el alto foro sostuvo la aplicación a ultranza de la forma escrita para negar existencia y validez de una relación negocial que podía probarse por otras vías; menosprecia la función económica del contrato que es bilateral y oneroso conmutativo; aplica de forma incorrecta las reglas de la interpretación contractual donde, para determinar y asignar el significado a la relación, deben tenerse en cuenta los actos anteriores, coetáneos y posteriores a la perfección del vínculo, la naturaleza 
del contrato y las prácticas de los sujetos involucrados; abandona el principio de la buena fe, toda vez que los trabajadores cumplieron con sus obligaciones confiando que su contraparte cumpliría con el deber de pagar el precio de los trabajos; vulnera el principio de interés general, contrario a lo que se argumenta en sentido de restablecerlo porque, como hemos dicho, es tan contrario a su esencia el hecho de que el ente público pague más de lo que vale el trabajo como que el cuentapropista no perciba lo justo por el hecho de cumplir su obligación. Y esta última es la respuesta elocuente a la segunda interrogante: la solución más valiosa y ajustada al interés general no es la que despoja a los sujetos de sus derechos legítimos, sino la que los obliga a cumplirlos en un ambiente de justicia equitativa.

\section{El interés general en la hermenéutica contractual cubana}

Desde el punto de vista de la interpretación contractual, el deber de las partes de cumplir con las regulaciones administrativas y no contravenir o dañar el interés público y la economía nacional impone el estricto apego a las normas específicas de la materia y las que fundan el sistema económico, político y social ${ }^{31}$. Los tribunales quedan impedidos de conceder validez a los acuerdos o transacciones que coloquen al Estado o sus entidades en situación de desequilibrio o desventaja evidente para el cumplimiento de una obligación contractual, procediendo a declarar la nulidad de la cláusula o contrato cuyo significado sea contrario o intente desconocer las prioridades económicas y sociales fijadas por el poder público.

En este sentido, la tarea interpretativa, según el interés general, opera como elemento discriminante y guía al momento de favorecer los efectos del contrato cuando el intérprete se enfrenta a la disyuntiva en la que un término o cláusula arroja diversas formas de ser comprendido, lo cual genera una multiplicidad de consecuencias jurídicas según el significado que se les asigne. En todo caso, aquellos significados que revelen efectos antagónicos con los intereses de la sociedad o el Estado serán excluidos y solo quedarán en salvaguarda aquellos compatibles -favor contractus-. De este modo, la previsión del artículo 67.a del Código Civil cubano ${ }^{32}$ es una expresión de este elemento axiológico y de la capilaridad constitucional.

Como cuestión lógica, no pueden ensayarse en la aplicación de este precepto criterios hermenéuticos de extremo, donde la aparente protección del interés general sacrifique el interés individual. El criterio de la armonía entre ambos extremos ha de ser el máximo. Es muy importante que los operadores jurídicos entiendan que el

31 Los artículos 7, 9 y 90 de la Constitución de la República de Cuba de 2019 constituyen asidero de este argumento, al impedir a todo ciudadano el ejercicio de las libertades reconocidas contra la Constitución y las leyes, ni contra la existencia y fines del Estado socialista. Cuestión resumida en el deber inexcusable de cumplir con lo dispuesto en la Carta Magna y en las demás normas jurídicas.

32 "Artículo 67. Son nulos los actos jurídicos realizados: a) en contra de los intereses de la sociedado el Estado. [...]." 
criterio que más tiende al interés general es aquel que se sustenta en su trascendencia frente al individual, y no aquel cimentado en el conflicto.

De vuelta a los casos relacionados en las sentencias 35, 36 y 37, del 31 de marzo de 2014, dictadas por la Sala de lo Económico del Tribunal Supremo Popular de la República de Cuba, sosteníamos que el tribunal había aplicado de forma incorrecta las reglas de interpretación contractual donde, para determinar y asignar el significado a la relación, deben tenerse en cuenta los actos anteriores, coetáneos y posteriores a la perfección del vínculo, la naturaleza del contrato y las prácticas de los sujetos involucrados ${ }^{33}$. Pero ¿cómo podrían armonizarse estos criterios hermenéuticos con el hecho de que los precios pactados en los contratos de prestación de servicios eran excesivos, vulneraban las regulaciones administrativas, contravenían el interés público y dañaban la economía nacional? Pues declarando nula la cláusula, o la parte de ella, que fijaba el precio exorbitante, aunque no en el sentido de dejar desprotegidos a quienes cumplieron con las obligaciones que les eran exigibles en virtud del acuerdo, sino con el objetivo de fijar un precio ajustado a la realidad del tráfico del momento, para ello debía seguirse el criterio de la naturaleza del contrato y las prácticas habituales de los sujetos en una situación similar. Cuestión que orienta los razonamientos en el cauce de la buena fe y exige la integración del contrato de conformidad con el artículo 63 del ya citado Decreto Ley n. . 304/2012.

Por otra parte, ni las empresas del Estado, ni los sujetos autorizados para gestionar bienes o sectores públicos podrán aprovechar su condición para obtener beneficios extraordinarios de otros sujetos más vulnerables impedidos de negociar o imposibilitados de elegir. El orden público, como se ha dicho antes, no es una tipología de interés general que abarca la esfera de lo estrictamente estatal, antes comporta una manifestación del fin solidario y protector que cumplen el Estado y la sociedad para con el individuo que busca satisfacer las necesidades de su vida material y espiritual, en las que el ente político-público tiene una especial responsabilidad ${ }^{34}$.

Atendiendo a este último planteamiento, el favor debilis, principio rector de la interpretación en los contratos predispuestos, donde una de las partes está en franca desventaja, manifiesta una fuerte tendencia a la realización del interés general o función social del contrato. Obviamente, otros principios, como la buena fe y la equidad, son decisivos en esta máxima de que la interpretación debe buscar el significado más favorable para el sujeto más débil, condición determinante de su baja o nula capacidad de negociación; pero a la vez demuestra la versatilidad del principio-valor y sus posibilidades de conjugación, manifiestas en su alta capacidad asociativa con otros valores y principios. Además, estas características del interés general maximizan su dimensión argumentativa para sustentar la decisión sin llegar a convertirse en lugar común o cliché.

33 Artículos 55.4, 58 y 60 del Decreto Ley n. . 304/2012.

34 Finnis, J., Ley natural y derechos naturales, trad. Cristóbal Orrego Sánchez, Buenos Aires, AbeledoPerrot, 2000, 179. 
La misión del intérprete, de conformidad con el orden social, no consiste únicamente en precisar el contenido de la cláusula, sino que debe velar por que los efectos que cada significado despliegue no arrojen un resultado injusto, socialmente negativo, donde el conflicto entre los sujetos de derecho y de estos con el Estado no cree graves situaciones de desamparo o explotación, como las que se generan por la existencia de las llamadas cláusulas o prácticas abusivas en la contratación masiva y, muy significativamente, en los contratos necesarios o de hecho. Así, la norma constitucional asume un papel sustancial y convierte los preceptos contentivos de los derechos humanos, y los que sustentan el sistema económico y social, en la base de su esquema de análisis ${ }^{35}$.

La sentencia n. ${ }^{\circ} 382$, del 19 de agosto de 2013, de la Sala de lo Civil y de lo Administrativo del Tribunal Supremo Popular de la República de Cuba, al trabarse el recurso extraordinario en un caso de cobertura de riesgo de un contrato de seguro de bienes para un vehículo automotor, es un caso ilustrativo. El recurrente argumentaba el inadecuado proceder del órgano de instancia cuando, al apreciar el significado del término "robo", acogía el propuesto por la entidad aseguradora, según el "Manual Operativo del Seguro de Vehículo de Transporte Terrestre", redactado por la propia entidad predisponente, conforme con el cual el término "robo" debía entenderse en el sentido técnico-jurídico de "robo con fuerza" o "robo con violencia" y no en el sentido de "hurto", que a la postre constituía el siniestro por el que el asegurado reclamaba la indemnización. Así las cosas, el alto foro dispuso en el primer considerando de su sentencia:

[...] al haberse calificado por la autoridad competente que la pérdida padecida configura el delito de hurto y que, al tratarse de una moto el vehículo sustraído, no puede soslayarse su exclusión prevista de los riesgos cubiertos, sin sustento en el contrato de seguro concertado entre las partes, en cuya ejecución se suscita el conflicto con motivo del siniestro acaecido [...].

Como resultado de la acogida del recurso, en el único considerando de la segunda sentencia, de igual fecha que el fallo de casación antes citado, la Sala Civil y Administrativa de la máxima instancia añade:

[...] que la entidad aseguradora está obligada a pagar la indemnización o suma asegurada correspondiente, conforme los dictados del inciso dos del artículo veintisiete del Decreto-Ley doscientos sesenta y tres de nueve de enero dos mil nueve (ocho), 'Del contrato de seguro' sin que sea válido argüir su exclusión, como infructuosa-

35 Ocando Ocando, H. y T. Pirela Izarra, "El estado social de derecho y de justicia: nuevo paradigma del Estado venezolano. Comentarios a la sentencia n. ${ }^{\circ}$ 85, expediente n. ${ }^{\circ}$ 01-1274 de la Sala Constitucional del Tribunal Supremo de Justicia de fecha 24/enero/2002”, Fronesis, Revista de Filosofía Jurídica, Social y Política, vol. 15, n. ${ }^{\circ}$ 2, 2008, 198. 
mente lo hace el representante procesal de la entidad demandada, por el tipo de vehículo y acontecimiento a que se refiere el asunto, a la sazón, el hurto de un motor, en el modo que se regula en el Manual Operativo del Seguro de Vehículo de Transporte Terrestre, que no tiene rango normativo y por tanto no deviene vinculante para los asegurados; por lo que no contemplado expresamente en la póliza, como lo exige el inciso e) del artículo quince de la Resolución número ocho de nueve de enero de dos mil nueve de la ministra de Finanzas y Precios, Reglamento del Decreto-Ley del Contrato de Seguro, carece de toda virtualidad a los fines de excepcionar la indemnización pretendida, estándose para ello al significado literal del contrato de seguro, en el sentido apuntado, a tenor de los dictados del inciso uno del artículo cincuenta y nueve del Decreto-Ley doscientos sesenta y tres del dos mil nueve [...].

Tratándose de un contrato sujeto a condiciones generales, como sucede con el seguro, el Tribunal Supremo maneja adecuadamente la idea de que tales condiciones poseen un carácter declarativo, en tanto pueden ser consideradas válidas y eficaces siempre que no sean contrarias a la buena fe y el equilibrio contractual, es decir, mientras no sean abusivas. De este modo, entender la cláusula en el sentido propuesto por la aseguradora es desproporcionado y antijurídico, por lo que asumirlo va contra la eficacia jurídica del contrato, su función en el tráfico y contra el interés general. Nótese que la necesidad de mantener con vida la relación no depende exclusivamente de un acuerdo de voluntades sustentado en la adhesión, sino en la función económica del vínculo, la buena fe y la equidad.

La razón de que, como acertadamente reconoce el Tribunal de Casación, la interpretación del término "robo" deba ceñirse al significado común, reside en aquel fundamento de última ratio. Como indica el artículo 59.1 del Decreto Ley n. ${ }^{\circ} 263$, "Del contrato de seguro", del 23 de diciembre de 2008, ajustar la interpretación al sentido literal u ordinario no es otra cosa que asignar a los términos empleados, el significado más corriente de una expresión en circunstancias análogas; por lo que "robo" entre ciudadanos comunes, como el asegurado, se refiere a todas las formas de apropiación ilícita de un bien ajeno y no la que sugiere la empresa al amparo de un manual de su exclusivo uso, que no conoce el adherente ni está obligado a conocer. En todo caso, el vínculo jurídico de las partes se infiere de lo consignado en la póliza, que es donde deben contenerse las exclusiones de cobertura, obligaciones de las partes, causas de pérdidas de derechos, así como las extensiones de cobertura de riesgos y los beneficios otorgados. Tales razones imponen a la entidad aseguradora aclarar exhaustivamente en el contrato el significado de los términos empleados cuando ellos implican alguno de los supuestos contenidos en el artículo 59 (nums. 4 y 5) del propio Decreto Ley n. ${ }^{\circ} 263$. Contrario sensu, la expresión que admita un significado ordinario y otro técnico debe preferir el primero al amparo de la buena fe y el favor debilis.

Ahora bien: el argumento de fondo que define el término "robo" en su sentido ordinario es el correlato de una combinación de factores, ubicados más allá de una estricta posición voluntarista de los sujetos que intervienen en la relación. A ella 
remite el legislador como forma de proteger el interés general, con fundamento en una justicia que tiene en cuenta las características de la contratación masiva y la tentativa de los sujetos preponderantes de maximizar sus utilidades con el empleo de tecnicismos que deroguen el significado habitual de las palabras que los sujetos adherentes asumen automáticamente y de buena fe.

De igual forma, los contratos no deben ser entendidos de modo que sus consecuencias jurídicas provoquen estragos al medio natural y pongan en riesgo o deterioren la reproducción de las capacidades vitales de los organismos vivos y sus hábitats, comprometiendo la salud humana y la seguridad colectiva. La supervivencia es uno de los retos que encara el mundo contemporáneo, y la actividad hermenéutica debe ser fiel veladora del impacto ambiental que pueden tener los negocios jurídicos ${ }^{36}$.

Por último, la capacidad expansiva e interdependiente del interés general se advierte en el conjunto de valores reconocidos en la Constitución de la República, donde destaca el artículo $1{ }^{\circ}$. El bien común en sí mismo constituye un valor, pero el quebrantamiento de alguno de los fines allí dispuestos es una forma de soslayar el interés general, siempre que la vulneración afecte de un modo amplio, cuantitativa o cualitativamente, los engranajes de cohesión social. Por tal motivo, cuando el contrato deje en evidencia una contraposición de tales dimensiones al contenido de los valores superiores, nada impide que pueda señalarse además la transgresión de la norma constitucional que contenga dichos valores, pudiendo alegarse que las partes han vulnerado el valor del bienestar colectivo actuando contra el interés general ${ }^{37}$.

36 El Código Civil argentino de 2014, en su artículo 14 in fine establece: "La ley no ampara el ejercicio abusivo de los derechos individuales cuando pueda afectar al ambiente [...]".

Los tribunales cubanos han reconocido como daño ambiental "[...] toda pérdida, disminución, deterioro o menoscabo significativo que se infiera al medio ambiente o a uno o más de sus componentes [...] por lo que toda persona natural o jurídica tiene la responsabilidad de proteger el medio ambiente y sus componentes, debiendo condicionar las actividades que se realicen al interés social de no causarle perjuicios o que puedan afectar la salud humana [...]". Sentencia n. ${ }^{\circ} 220$, del 30 de agosto del 2013, Sala de lo Económico del Tribunal Provincial Popular de La Habana.

37 Parece meridiana, en este sentido, la postura de la Sala Constitucional del Tribunal Supremo de Justicia de la República Bolivariana de Venezuela, el que en la histórica sentencia n. ${ }^{\circ} 85$, del 24 de enero de 2002, sostuvo: "Ni la autonomía de la voluntad, ni la libertad contractual pueden lesionar los beneficios que produce el Estado Social, contrariándolo, al contribuir a discriminaciones, subordinaciones, ruptura de la justicia social o desigualdades lesivas, por desproporcionadas, para una de las partes del contrato en materia de interés social.

"[...] es el bien común, sin desigualdades ni discriminaciones, sin abusos, el objetivo del Estado Social de Derecho, y tanto en las leyes como la interpretación constitucional deberán propender a él. Esta finalidad, necesariamente, limita la autonomía de la voluntad contractual, y a la actividad económica irrestricta, que permite a las personas realizar todo aquello que la ley no prohíba expresamente, así sea en perjuicio de la población o de grupos".

Por su parte, el Superior Tribunal de Justicia de Brasil, amparado en el interés general y la función social del contrato, ha negado la ejecución hipotecaria para el cobro de los créditos otorgados a empresas constructoras de viviendas, con el objetivo de proteger a los adquirentes, quienes ya habían pagado sumas por adelantado a las empresas constructoras. STJ, 4. ${ }^{\text {a }}$ T., recurso especial n. ${ }^{\circ} 187.940-$ SP, relator ministro Ruy Rosado de Aguiar Jr., del 18 de febrero de 1999 y 3. ${ }^{\text {a }}$ T., recurso especial n. ${ }^{\circ}$ 316.640-PR, relatora ministra Nancy Andrighi, del 18 de mayo de 2004. 
La Constitución es Ley Suprema, y todas sus normas, incluidas las contentivas de valores y principios, son directamente aplicables por todos los operadores jurídicos. Actualmente, la jurisprudencia de otras latitudes ha demostrado que la aplicación de los valores y los principios puede ser muy útil en la decisión de casos donde los tradicionales medios de interpretación no ofrecen la solución más adecuada y justa, siempre con la debida argumentación por parte de los jueces ${ }^{38}$.

\section{Conclusiones}

Con base en las apreciaciones vertidas podemos concluir las siguientes ideas:

El interés general revela su existencia y utilidad mediante la interdependencia positiva de los sujetos individuales y colectivos para alcanzar sus fines (bien común), lo cual determina la relación trascendental y no antagónica entre el bien colectivo y el individual; la realización de los diferentes intereses en el marco de la equidad y la justicia, teniendo en cuenta que no siempre el actuar del ente político público se sitúa en los marcos del interés general; y la imposibilidad de precisar su contenido fuera de una situación concreta.

La entrada al escenario legal cubano del interés general como uno de los principios que rigen la hermenéutica contractual significó un importante paso de apertura a la constitucionalización del proceso de interpretación de los contratos, el reforzamiento del esquema interpretativo de los contratos y el reajuste del significado e influencia de la autonomía de la voluntad en el ciclo. De este modo la función social del contrato, materialización de aquel en el ámbito negocial, permite contrastar la influencia de factores políticos, ideológicos y morales que constituyen una prueba fehaciente de los elementos que actúan repetidamente sobre la comprensión de la declaración de voluntad y que aportan dosis importantes de ponderación y equidad a la solución de las controversias.

En Argentina, Corte Suprema de Justicia de la Nación, en fallo del 23 de febrero de 1993, JA 1994III, ha sostenido: "La típica forma de producir en masa y la función social del seguro exigen que la autoridad de control disponga de los medios indispensables para salvaguardar los fines que le son propios y el bien común específico ínsito en ella. De allí las extensas facultades de control y decisión de la Superintendencia de Seguros y la necesidad de reconocer al organismo una razonable amplitud para apreciar los factores y datos técnicos que entran en juego en la materia".

38 La supra citada sentencia n. ${ }^{\circ} 85$, del 24 de enero de 2002, de la Sala Constitucional del Tribunal Supremo de Justicia de Venezuela sostiene: "La Constitución antepone el bien común (el interés general) al particular, y reconoce que ese bien común se logra manteniendo la solidaridad social, la paz y la convivencia. En consecuencia, las leyes deben tener por norte esos valores, y las que no lo tengan, así como las conductas que fundadas en alguna norma, atenten contra esos fines, se convierten en inconstitucionales [...] el interés social gravita sobre actividades tanto del Estado como de los particulares, porque con él se trata de evitar un desequilibrio que atente contra el orden público, la dignidad humana y la justicia social [...] en materia de interés social, el imposible cumplimiento de las obligaciones contraídas por el débil jurídico o la excesiva onerosidad del negocio, que se convierte en una inconformidad con el contrato, producto de una transformación imprevisible de la situación jurídica, nacida conforme a la ley, puede conllevar a la inconstitucionalidad de la norma en que se fundó la relación jurídica, si el resultado de la aplicación de la ley choca con los valores tutelados por la Constitución, debido a que dicha aplicación causó una situación que contraría principios constitucionales". 


\section{Referencias}

Alexy, R., Teoría de los derechos fundamentales, trad. español Ernesto Garzón Valdés, Madrid, Editorial Centro de Estudios Constitucionales, 1993.

Arredondo Suárez, I. I., “¿Principios generales del Derecho en el sistema de fuentes?", "Justicia y Derecho", Revista del Tribunal Supremo Popular de la República de Cuba, n. ${ }^{\circ}$ 14, año 8, junio de 2009.

Ávila Santamaría, R., "Ecuador, Estado constitucional de derecho y de justicia”, en AA. vv., La Constitución del 2008 en el contexto andino. Análisis desde la doctrina y el derecho comparado, 1. ${ }^{\text {a }}$ ed., Quito, Editorial del Ministerio de Justicia y Derechos Humanos, 2008.

Benetti Timm, L., "La función social del Derecho contractual en el Código Civil brasileño: justicia distributiva vs. eficiencia económica", Revista de Instituciones, ideas y mercados, $\mathrm{n} .^{\circ}$ 52, mayo de 2010.

Bernal Fandiño, M., El deber de coherencia en el Derecho colombiano de los contratos, 1. a ed., Bogotá, Editorial de la Pontificia Universidad Javeriana, 2013.

Bruzón Viltres, C. J. y I. R. Tamayo Blanco, "La jurisprudencia en Cuba: reconocimiento dentro del sistema de fuentes del Derecho y posibles consecuencias", Boletín Mexicano de Derecho Comparado, año XLVII, n. ${ }^{\circ}$ 139, enero-abril 2014.

Bruzón Viltres, C. J., Condiciones para la validez formal de la jurisprudencia como fuente del Derecho en Cuba, tesis presentada en opción al grado científico de Doctor en Ciencias Jurídicas, Universidad de Oriente, Santiago de Cuba, 2016.

Constant, B., Curso de política constitucional, t. 2, trad. Marcial Antonio López, Madrid, Imprenta de la Compañía, 1820.

Constant, B., Sobre la libertad de los antiguos y en los modernos, Madrid, Tecnos, 2002.

Cruz Prados, A., Ethos y Polis. Bases para una reconstrucción de la Filosofía Política, Pamplona, EunSA, 1999.

DE Cores, C. A. y J. M. CAL, "El concepto de interés público y su incidencia en la contratación administrativa", Revista de Derecho de la Universidad de Montevideo, n. ${ }^{\circ} 11$, año VI, 2007. 
De la Torre Martínez, C., La recepción de la Filosofía de los Valores en la Filosofía del Derecho, 1. 'ad., México, D. F., unAm, 2005.

DE VEGA, P., "La democracia como proceso (consideraciones en torno al republicanismo de Maquiavelo)", Revista de Estudios Políticos (Nueva época), n. ${ }^{\circ}$ 120, abril-junio, 2003.

Del Rosario Rodríguez, M. F., "La supremacía constitucional: naturaleza y alcances", Díkaion, año 25, vol. 20, n. ${ }^{\circ}$ 1, 2011, disponible en [https://dikaion .unisabana.edu.co/index.php/dikaion/article/view/1950] [consultado el 12 de enero de 2018].

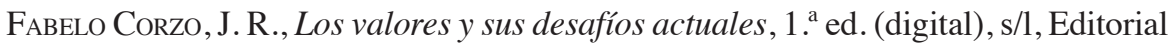
Libros en Red, 2004.

FinNIS, J., Ley natural y derechos naturales, trad. Cristóbal Orrego Sánchez, Buenos Aires, Abeledo-Perrot, 2000.

García Rosales, L. Á., "La discriminación, el derecho de admisión y el derecho a la igualdad”, en AA. vv., Principios y valores constitucionales, Bogotá, Ediciones "Civilizar", 2005.

Garzón VAllejo, I., "Bien común, pluralismo y derechos”, en AA. vv., Ley, moral y razón. Estudios sobre el pensamiento de John M. Finnis a propósito de la edición de Ley natural y derechos naturales, Juan B. Etcheverry (Editor), 1. a ed., México, D. F., Instituto de Investigaciones Jurídicas unam, 2013.

Grillo Longoria, R., Derecho Procesal Civil, t. i. Teoría General del Proceso Civil, 3. ${ }^{\text {a ed., 1. }}$ a reimp., La Habana, Félix Varela, 2006.

Hart, H. L. A.: El concepto del Derecho, 1. a ed. inglesa, trad. Genaro R. Carrió, Buenos Aires, Abeledo-Perrot, 1998.

Huerta Ochoa, C., "El concepto de interés público y su función en materia de seguridad nacional”, en AA. vV., Seguridad pública. Segundo Congreso Iberoamericano de Derecho Administrativo, Cisneros Farías, G; J. Fernández Ruiz y M. A. López Olvera (coords.), 1. ed., México, D. F., Instituto de Investigaciones Jurídicas UNAM, 2007.

Kelsen, H., Teoría Pura del Derecho, 1. ${ }^{\mathrm{a}}$ ed, 2. ${ }^{\mathrm{a}}$ reimp., trad. 2. ${ }^{\mathrm{a}}$ ed. alemana Roberto J. Vernengo, México, D. F., Instituto de Investigaciones Jurídicas unam, 1982. 
López Calera, N., "El interés público: entre la ideología y el Derecho", Anales de la Cátedra Francisco Suárez, Universidad de Granada, n. . 44, 2010.

Marco Perles, G. S., "Bien común e interés general en la retórica de los poderes públicos: ¿conceptos intercambiables?”, Anuario Filosófico, XLII, 3, 2009.

Mariño Castellanos, Á. R.; Méndez López, J. y D. Cutié Mustelier, “Los valores superiores del ordenamiento jurídico, pilar básico del texto constitucional”, Barco de Papel, Memorias de la IV Conferencia Científica sobre Derecho, Facultad de Derecho de la Universidad de Oriente-Facultad de Derecho Eugenio María de Hostos, Mayagüez de Puerto Rico, 6-8 de octubre, 1997.

Martí, J., "Discurso en el Liceo cubano, Tampa, 26 de noviembre de 1891”, Obras Completas, vol. 4, Política y Revolución IV, 1895. Discursos Revolucionarios, La Habana, Centro de Estudios Martianos y Karisma Digital, 2001.

Mendoza Díaz, J., "Las fuentes formales del Derecho Procesal Civil”, en AA. vv., Lecciones de Derecho Procesal Civil, 2. ' reimp., La Habana, Félix Varela, 2009.

Moráis Carvalho, J., "La protección de los consumidores en la Unión Europea. ¿Mito o realidad?”, Criterio Jurídico, Pontificia Universidad Javeriana, vol. 6, 2006, 243-266.

Ocando Ocando, H. y T. Pirela Izarra, "El estado social de derecho y de justicia nuevo paradigma del Estado venezolano. Comentarios a la sentencia n. ${ }^{\circ} 85$, expediente n. ${ }^{\circ}$ 01-1274 de la Sala Constitucional del Tribunal Supremo de Justicia de fecha 24/enero/2002", Fronesis, Revista de Filosofía Jurídica, Social y Política, vol. 15, n. $^{\circ} 2,2008$.

Pacheco G., M., Teoría del derecho, 4. ${ }^{a}$ ed., Santiago de Chile, Editorial Jurídica de Chile, 1990.

Peces-Barba, G., Introducción a la Filosofía del Derecho, Madrid, Editorial Debate, 1990.

Peces-Barba, G., Los valores superiores, Colección Temas Claves de la Constitución Española, Madrid, Tecnos, 1984.

Pérez Gallardo, L. B., "Breves notas sobre el Código Civil cubano a propósito de los veinte años de su promulgación. Especial referencia al Derecho de obligaciones y contratos", Revista Cubana de Derecho, n. ${ }^{\circ}$ 30, julio-diciembre, 2007. 


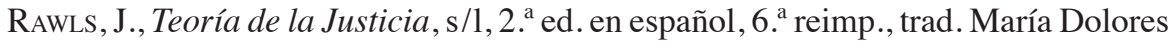
González, México, D. F., Fondo de Cultura Económica, 2006.

Ríos Álvarez, L., "Trascendencia de los valores en las Constituciones Políticas de Chile y España”, en Estudios Constitucionales, Revista del Centro de Estudios Constitucionales de Chile, año 1, n. ${ }^{\circ} 1,2003$.

RodrígueZ-Arana, J., "El interés general en el derecho administrativo: notas introductorias", Revista Ópera Prima de Derecho Administrativo, Instituto de Investigaciones Jurídicas UnAM, n. ${ }^{\circ}$ 11, enero-junio, 2012, 69-96.

Rouseau, J. J., El Contrato Social o Principios de Derecho Político, s/1, Ediciones elaleph.com, 1999.

Sánchez de Bustamante y Montoro, A., Introducción a la Ciencia del Derecho, Nociones liminares: El Derecho, vol. 1, La Habana, Jesús Montero (ed.), 1942.

Santiago Nino, C., "Justicia", Doxa, n. ' 14, 1993.

VILloro, L., El poder y el valor. Fundamentos de una ética política , 1. a ed., 6. ' reimp., México, D. F., Fondo de Cultura Económica “El Colegio Nacional”, 2012.

Von IHERING, R., El fin en el Derecho, trad. Leonardo Rodríguez, Madrid, B. Rodríguez Serra Editor, s/f.

Zenedin Glitz, F. E., La globalización del derecho contractual, trad. María Noel Antas, Sao Paulo, Editora Clásica, 2012.

\section{Normas jurídicas}

Código Civil brasileño de 2002.

Código Civil de la República de Cuba de 1987.

Código Civil de la República de Chile de 1857.

Código Civil de la República de El Salvador de 1859.

Código Civil de la República de Italia de 1942.

Código Civil del Reino de España 1888.

Código Civil Federal de los Estados Unidos Mexicanos de 1928. 
Código Civil francés de 1804.

Código Civil y Comercial de la Nación Argentina de 2014.

Constitución de la República Bolivariana de Venezuela de 1999.

Constitución de la República de Cuba de 1901.

Constitución de la República de Cuba en Armas (Constitución de Guáimaro), del 10 de abril de 1869 .

Constitución de la República de Cuba en Armas (Constitución de Jimaguayú), del 16 de septiembre de 1895 .

Constitución de la República de Cuba en Armas (Constitución de la Yaya), del 30 de octubre de 1897.

Constitución de la República de Cuba del 10 de octubre de 1940.

Constitución de la República de Cuba de 1976, reformada en el año 1992 y 2002.

Constitución de la República de Cuba del 10 de abril de 2019, en Gaceta Oficial de la República de Cuba, Extraordinaria, n. ${ }^{\circ}$ 5, del 10 de abril de 2019.

Constitución de la República del Ecuador de 2008.

Constitución de la República Francesa de 1958.

Constitución del Reino de España de 1978.

Constitución Política de Colombia de 1991.

Constitución Política del Estado Plurinacional de Bolivia de 2009.

Decreto Ley n. ${ }^{\circ}$ 263, Del contrato de Seguro, 23 de diciembre de 2008, Gaceta Oficial de la República de Cuba, Edición Extraordinaria, n. ${ }^{\circ}$ 5, 26 de enero de 2009.

Decreto Ley n. ${ }^{\circ} 304$, De la contratación económica $1 .^{\circ}$ de noviembre de 2012, Gaceta Oficial de la República de Cuba, Ed. Extraordinaria, n. ${ }^{\circ} 62,27$ de diciembre de 2012 .

Ley Fundamental de la República Federal Alemana de 1949. 


\section{Resoluciones judiciales}

Sentencia n. ${ }^{\circ}$ 219, del 31 de marzo de 2006, de la Sala de lo Civil y de lo Administrativo del Tribunal Supremo Popular de la República de Cuba.

Sentencia n. ${ }^{\circ}$ 382, del 19 de agosto de 2013, de la Sala de lo Civil y de lo Administrativo del Tribunal Supremo Popular de la República de Cuba

Sentencia n. ${ }^{\circ} 33$, del 31 de marzo de 2014, de la Sala de lo Económico del Tribunal Supremo Popular de la República de Cuba.

Sentencia n. ${ }^{\circ}$ 35, del 31 de marzo de 2014, de la Sala de lo Económico del Tribunal Supremo Popular de la República de Cuba.

Sentencia n. ${ }^{\text {o } 36, ~ d e l ~} 31$ de marzo de 2014, de la Sala de lo Económico del Tribunal Supremo Popular de la República de Cuba.

Sentencia n. ${ }^{\circ}$ 37, del 31 de marzo de 2014, de la Sala de lo Económico del Tribunal Supremo Popular de la República de Cuba.

Sentencia n. ${ }^{\circ} 220$, del 30 de agosto de 2013, Sala de lo Económico del Tribunal Provincial Popular de La Habana.

Sentencia n. ${ }^{\circ}$ 35, del 18 de marzo del 2015, de la Sala de lo Económico del Tribunal Provincial Popular de La Habana, República de Cuba.

Sentencia n. ${ }^{\circ} 85$, del 24 de enero de 2002, de la Sala Constitucional del Tribunal Supremo de Justicia de la República Bolivariana de Venezuela.

Superior Tribunal de Justicia de Brasil, 4. ${ }^{\text {a }}$ T., recurso especial n. ${ }^{\circ}$ 187.940-SP, relator ministro Ruy Rosado de Aguiar Jr., del 18 de febrero de 1999, y 3. a T., recurso especial n. ${ }^{\circ}$ 316.640-PR, relatora ministra Nancy Andrighi, del 18 de mayo de 2004.

Corte Suprema de Justicia de Argentina, fallo del 23 de febrero de 1993, JA 1994-III.

Sentencia 19-VII-1996 de la Corte Suprema de Justicia de la República de El Salvador.

Sentencia C-539 de 1999, ratificada por la sentencia C-053, del 23 de enero de 2001, Corte Constitucional de la República de Colombia.

Sentencia Serie C n. ${ }^{\circ} 222$, del 3 de marzo de 2011, "Salvador Chiriboga vs. Ecuador", Corte Interamericana de Derechos Humanos, disponible en [www.corteidh.or.cr/ CF/jurisprudencia2/ficha_tecnica.cfm?nId_Ficha=292], consultado: 13/09/2019. 